\title{
Effects of a Novel Calcium Aluminate Cement on the Early Events of the Progression of Osteogenic Cell Cultures
}

\author{
Larissa Moreira Spinola de CASTRO-RAUCCI ${ }^{1}$ \\ Ivone Regina de OLIVEIRA ${ }^{2}$ \\ Lucas Novaes TEIXEIRA ${ }^{1}$ \\ Adalberto Luiz ROSA ${ }^{1}$ \\ Paulo Tambasco de OLIVEIRA ${ }^{1}$ \\ Marcos JACOBOVITZ ${ }^{3}$ \\ ${ }^{1}$ Ribeirão Preto Dental School, USP - University of São Paulo, Ribeirão Preto, SP, Brazil \\ ${ }^{2}$ UFSCar - Federal University of São Carlos, São Carlos, SP, Brazil \\ ${ }^{3} A P C D$ - The São Paulo State Dental Association, São Carlos, SP, Brazil
}

\begin{abstract}
The present study evaluated the progression of osteogenic cell cultures exposed to a novel calcium aluminate cement $(\mathrm{CAC}+)$ in comparison with the gold standard mineral trioxide aggregate (MTA). Cells were enzimatically isolated from newborn rat calvarial bone, plated on glass coverslips containing either CAC + or a control MTA samples in the center, and grown under standard osteogenic conditions. Over the 10-day culture period, roundening of sample edges was clearly noticed only for MTA group. Although both cements supported osteogenic cell adhesion, spreading, and proliferation, CAC+-exposed cultures showed significantly higher values in terms of total cell number at days 3 and 7 , and total protein content and alkaline phosphatase activity at day 10. The present in vitro results indicate that the exposure to $\mathrm{CAC}+$ supports a higher differentiation of osteogenic cells compared with the ones exposed to MTA. Further experimental studies should consider CAC + as a potential alternative to MTA when the repair of mineralized tissues is one of the desired outcomes in endodontic therapy.
\end{abstract}

Key Words: calcium aluminate cement, mineral trioxide aggregate, cell culture, osteoblast, alkaline phosphatase.

\section{INTRODUCTION}

The cellular response to mineral trioxide aggregate (MTA) is already well established in the literature. Several in vitro and in vivo studies concerning cell and tissue interactions with MTA have demonstrated its biocompatible nature (1-4). Despite that, MTA presents some negative characteristics, such as sandy consistency (poor handling characteristics), poor dispersion, high porosity (5), long setting time, tooth and gingival darkening (6), initial solubility when used as a root-end filling material (7), and high cost. Therefore, changes in formulation/composition of mineral aggregates and development of new branches on this class of materials have been proposed aiming to improve its physicalchemical characteristics $(5,8,9)$.
In this context, Pandolfelli et al. (5) developed a novel calcium aluminate cement composed by $\mathrm{Al}_{2} \mathrm{O}_{3}$ (68.5 $\mathrm{wt} \%$ ) and $\mathrm{CaO}(29.5 \mathrm{wt} \%)$ plus additives (hereafter referred to as $\mathrm{CAC}+$ ). Such cement was designed to overcome some negative MTA characteristics by shortening setting time, reducing porosity and pore sizes, improving strength under compressive loads, promoting flow ability and reducing stain ability, while maintaining the satisfactory properties and clinical applications that MTA preparations provide (10).

The physical-chemical properties of $\mathrm{CAC}+$ in comparison with the gold standard MTA have recently been described (11). In addition, the forming chemicalmechanical barrier against bacterial microleakage may attest the possibility for its multipurpose use in Endodontics (12). However, the impact of the exposure

Correspondence: Prof. Dr. Paulo Tambasco de Oliveira / Dr. Marcos Jacobovitz, Departamento de Morfologia, Estomatologia e Fisiologia, Faculdade de Odontologia de Ribeirão Preto, USP, Avenida do Café, S/N, 14040-904 Ribeirão Preto, SP, Brasil. Tel: +55-16-3602-3978. Fax: +55-16-36330999. e-mail: tambasco@usp.br 
of $\mathrm{CAC}+$ to mineralized tissue-forming cells remains to be assessed. Thus, the present in vitro study evaluate comparatively the effects of both mineral aggregate cements, MTA and CAC+, on early events of the progression of osteogenic cell cultures.

\section{MATERIAL AND METHODS}

\section{MTA and CAC+ Sample Preparation}

The mineral aggregates used were: WhiteMTA (Angelus, Londrina, PR, Brazil) and CAC+ (5). Both cement pastes were handled with sterile water in a proportion of 3 parts of powder to one part of bidistilled water in volume, according to the manufacturer instructions. Then, MTA and CAC samples (4 $\mathrm{mm}$ in diameter and $2 \mathrm{~mm}$ height) were forged in a silicon mold, and after the final set 21 days later, the samples were detached from it and weighted. The sample mass was approximately $40 \mathrm{mg}(39.9 \pm 3.7)$. Then, each sample was glued with a cyanoacrylate gel (Loctite, Henkel Technologies, Diadema, SP, Brazil) to the center of a round glass coverslip, $12 \mathrm{~mm}$ in diameter (Fisher Scientific Inc., Suwanee, GA, USA). The ensembles (sample + glass coverslip) were then sterilized by gamma rays (Embrarad, Cotia, SP, Brazil) and placed in 24-well polystyrene plates (Falcon, Franklin Lakes, NJ, USA) for cell culture experiments. The effect of cyanoacrylate on cell proliferation/viability was evaluated in preosteoblastic MC3T3-E1 cells (ATCC, Manassas, VA, USA) by means of MTT assay (described below).

\section{Cell Isolation and Primary Culture of Osteogenic Cells}

Osteogenic cells were isolated by sequential trypsin/collagenase digestion of calvarial bone from newborn (2-4 days) Wistar rats, as previously described (13). All animal procedures were in accordance with the guidelines of the Animal Research Ethics Committee of the University of São Paulo. Cells were plated on glass coverslips with either a MTA or a CAC + sample at a cell density of 20,000 cells/well. The osteogenic culture medium comprised of Gibco $\alpha$-Minimum Essential Medium with L-glutamine (Invitrogen, Carlsbad, CA, USA) supplemented with $10 \%$ fetal bovine serum (Invitrogen), $7 \mathrm{mM} \beta$-glycerophosphate (Sigma, St. Louis, MO, USA), $5 \mu \mathrm{g} / \mathrm{mL}$ ascorbic acid (Sigma), and $50 \mu \mathrm{g} / \mathrm{mL}$ gentamicin (Invitrogen). The plated cells were grown for periods up to 10 days at $37^{\circ} \mathrm{C}$ in a humidified atmosphere with $5 \% \mathrm{CO}_{2}$. The culture medium was changed every 2-3 days. The progression of cultures was examined by phase contrast microscopy (Axiovert 25, Carl Zeiss, Jena, Germany).

\section{Cell Morphology}

At days 3 and 7, cells were fixed for $10 \mathrm{~min}$ at room temperature (RT) using 4\% paraformaldehyde in $0.1 \mathrm{M}$ sodium phosphate buffer (PB), $\mathrm{pH}$ 7.2. After washing in $\mathrm{PB}$, cultures were processed for direct fluorescence labeling (13). Briefly, they were permeabilized with $0.5 \%$ Triton X-100 in PB for $10 \mathrm{~min}$ and incubated with Alexa Fluor 488 (green fluorescence)-conjugated phalloidin (1:200, Molecular Probes, Invitrogen) for 50 min at RT in a humidified environment, for the detection of actin cytoskeleton and cell periphery. Between each incubation step, the samples were washed in PB (3 x $5 \mathrm{~min}$ ). Before mounting for microscope observation, samples were briefly washed with $\mathrm{dH}_{2} \mathrm{O}$ and cell nuclei stained with $300 \mathrm{nM}$ 4',6-diamidino-2-phenylindole, dihydrochloride (DAPI, Molecular Probes) for $5 \mathrm{~min}$. After carefully detaching MTA or CAC + samples, the glass coverslips were placed face down on glass slides and mounted with Vectashield antifade (Vector Laboratories, Burlingame, CA, USA). The samples were then examined under epifluorescence using a Leica DMLB light microscope (Leica, Bensheim, Germany), with N Plan (X10/0.25, X20/0.40) and HCX PL Fluotar (X40/0.75) objectives, outfitted with a Leica DC 300F digital camera, 1.3 Megapixel CCD. The acquired digital images were processed with Adobe Photoshop software (version 7.0, Adobe Systems Inc., San Jose, CA, USA).

\section{Total Cell Number}

Cells grown for periods of 3 and 7 days were enzymatically detached from glass coverslips using 1.3 $\mathrm{mg} / \mathrm{mL}$ collagenase and $0.25 \%$ trypsin solution (Gibco, Invitrogen). Total number of cells/well was determined after Trypan blue (Sigma) staining using a hemacytometer (Hausser Scientific, Horsham, PA, USA).

\section{Cell Proliferation/Viability}

Cell proliferation/viability was evaluated by 3-[4,5-dimethylthiazol-2-yl]-2,5-diphenyltetrazolium bromide (MTT, Sigma) assay at days 3, 7 and 10 (14). Cells were incubated with $10 \%$ MTT $(5 \mathrm{mg} / \mathrm{mL})$ in culture 
medium at $37^{\circ} \mathrm{C}$ for $4 \mathrm{~h}$. The medium was then aspirated from the well, and $1 \mathrm{~mL}$ of acid isopropanol $(0.04 \mathrm{~N}$ $\mathrm{HCl}$ in isopropanol) was added to each well. The plates were then stirred on a plate shaker for $5 \mathrm{~min}$, and 200 $\mu \mathrm{L}$ of this solution was transferred to a 96-well format using opaque-walled transparent-bottomed plates (Fisher Scientific Inc.). Optical density was read at $570 \mathrm{~nm}$ on the plate reader ( $\mu$ Quant; Bio-Tek Instruments, Winooski, VT, USA), and data were expressed as absorbance.

\section{Total Protein Content and Alkaline Phosphatase Activity}

Total protein content was determined at day 10 by using a modification of the Lowry method (13). Briefly, proteins were extracted from each well with $0.1 \%$ sodium lauryl sulphate (Sigma) for 30 min and mixed 1:1 with Lowry solution (Sigma) for $20 \mathrm{~min}$ at RT. The extract was diluted in Folin and Ciocalteau's phenol reagent (Sigma) for $30 \mathrm{~min}$ at RT. Absorbance was measured at $680 \mathrm{~nm}$ using a spectrophotometer (Cecil CE3021, Cambridge, UK). The total protein content was calculated from a standard curve and expressed as $\mu \mathrm{g} / \mathrm{mL}$.

Alkaline phosphatase (ALP) activity was assayed in the same lysates used for determining total protein content as the release of thymolphthalein from thymolphthalein monophosphate by using a commercial kit (Labtest Diagnóstica, Lagoa Santa, MG, Brazil). Briefly, $50 \mu \mathrm{L}$ of thymolphthalein monophosphate were mixed with $0.5 \mathrm{~mL}$ of $0.3 \mathrm{M}$ diethanolamine buffer, $\mathrm{pH}$

Table 1. Quantitative analysis (mean $\pm \mathrm{SD})$ of total cell number $\left(\mathrm{x} 10^{4}\right)$, cell viability (absorbance, $570-650 \mathrm{~nm}$ ), total protein content $(\mu \mathrm{g} / \mathrm{mL}$ ), and alkaline phosphatase (ALP) activity ( $\mu \mathrm{mol}$ thymolphthalein/h/mg protein) of osteogenic cell cultures grown in the presence of either MTA or CAC + .

\begin{tabular}{lcccc}
\hline Parameters & $\begin{array}{c}\text { Time } \\
\text { points } \\
\text { (days) }\end{array}$ & MTA & CAC + & $\begin{array}{c}\text { Significance } \\
\text { level }\end{array}$ \\
\hline Total cell number & 3 & $0.7 \pm 0.2$ & $1.4 \pm 0.1$ & $\mathrm{p}=0.001$ \\
& 7 & $5.5 \pm 0.1$ & $7.7 \pm 1.6$ & $\mathrm{p}=0.048$ \\
Cell viability & 3 & $0.017 \pm 0.007$ & $0.024 \pm 0.007$ & $\mathrm{p}>0.05$ \\
& 7 & $0.107 \pm 0.046$ & $0.111 \pm 0.025$ & $\mathrm{p}>0.05$ \\
Total protein content & 10 & $0.103 \pm 0.042$ & $0.158 \pm 0.050$ & $\mathrm{p}>0.05$ \\
ALP activity & 10 & $21.5 \pm 2.2$ & $36.9 \pm 3.6$ & $\mathrm{p}=0.001$ \\
\hline
\end{tabular}

10.1 , and left for $2 \mathrm{~min}$ at $37^{\circ} \mathrm{C}$. The solution was then added to $50 \mu \mathrm{L}$ of the lysates obtained from each well for $10 \mathrm{~min}$ at $37^{\circ} \mathrm{C}$. For color development, $2 \mathrm{~mL}$ of $0.09 \mathrm{M}$ $\mathrm{Na}_{2} \mathrm{CO}_{3}$ and $0.25 \mathrm{M} \mathrm{NaOH}$ were added. After $30 \mathrm{~min}$, absorbance was measured using a spectrophotometer (CE3021) at $590 \mathrm{~nm}$ and ALP activity was calculated from a standard curve using thymolphthalein to give a range from 0.012 to $0.4 \mu \mathrm{mol}$ thymolphthalein $/ \mathrm{h} / \mathrm{mL}$. Data were expressed as ALP activity normalized for total protein content. Some cultures were also stained with Fast red, as described elsewhere (15), for in situ histochemical detection of ALP activity.

\section{Statistical Analysis}

Data are presented as mean \pm SD. Comparisons were carried out using either two-way analysis of variance or Student's t-test for two independent samples, where appropriate. The significance level was set at $5 \%$.

\section{RESULTS}

Results for total cell number, cell viability, total protein content, and ALP activity of the osteogenic cell cultures under the tested conditions are given on Table 1. Although MTA and CAC+ samples remained fixed in the central area of the glass coverslips during the whole culture period, $\mathrm{CAC}+$ samples appeared to be more stable than the MTA ones. Importantly, roundening of sample edges was clearly noticed only for MTA group.

At day 3, epifluorescence revealed well-spread, adherent cells for both groups, mostly exhibiting a polygonal shape (Fig. 1A,B). Cells with typical morphologies of migrating cells on two-dimensional substrates and cells undergoing mitosis could also be observed. At day 7, whereas cell confluence occurred for both groups, a larger area with no cells (inhibition zone) could be observed circumjacently to MTA samples (Fig. 1, compare $\mathrm{C}$ with $\mathrm{D})$. In addition, a higher cell density was clearly noticed for CAC+ group (Fig. 1, compare $F$ with E). The presence of $\mathrm{CAC}+$ samples supported the differentiation of more Fast red-stained cells and with a higher staining intensity, mostly in areas of initial cell multilayering (Fig. 1, compare $\mathrm{H}$ with $\mathrm{G}$ ). 
At 3 and 7 days, the total cell number was significantly higher for cultures exposed to CAC+ (Student's t-test, $p=0.001$ and $p=0.048$, respectively) (Fig. 2A). MTT assay showed that cell proliferation/ viability was affected by the culture period ( 3 day $<7$ days $=10$ days), but not by the experimental group (two-way
ANOVA, $p=0.001$ and $p=0.132$, respectively) (Fig. 2B). In addition, exposure to cyanoacrylate only did not affect MC3T3-E1 cell proliferation/viability (not shown). At day 10 , total protein content and ALP activity was significantly higher (Student's t-test, $p=0.001$ ) for cultures grown in the presence of $\mathrm{CAC}+$ samples (Fig. 3A,B).
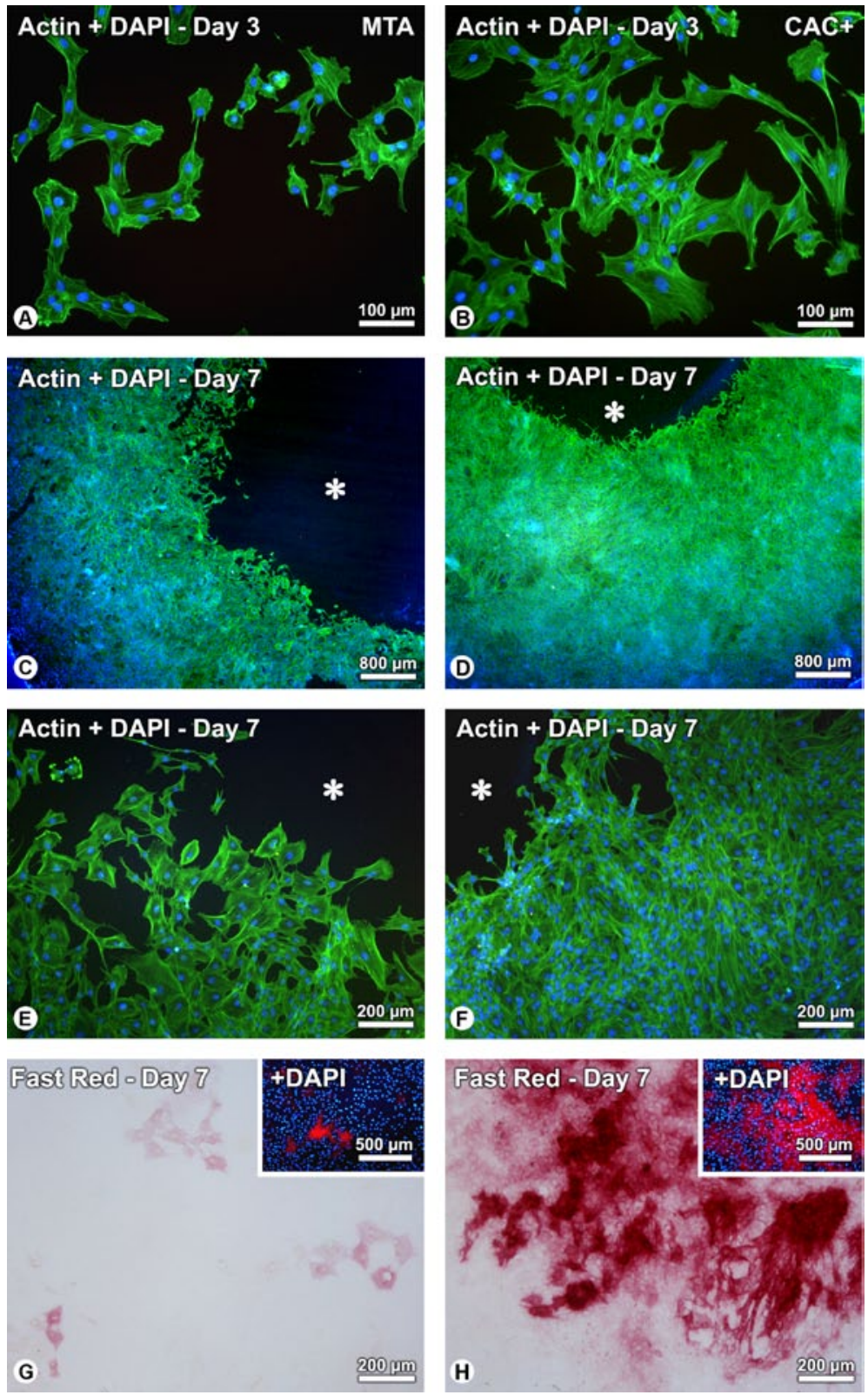

Figure 1. Calvaria-derived osteogenic cell cultures grown on glass coverslips in the presence of either MTA(A,C,E,G) or CAC+ (B,D,F,H) samples at days $3(\mathrm{~A}, \mathrm{~B})$ and 7 (C-H). At day 3, epifluorescence of actin cytoskeleton labeling (phalloidin labeling, green fluorescence) and DNA stain (DAPI, blue fluorescence) showed well-spread, adherent cells for both groups, mostly exhibiting a polygonal shape (A,B). At day 7, whereas primary cultures reached confluence for both groups, a larger area with no cells could be observed adjacent to the MTA sample (compare C with D); a higher cell density was clearly evident for the CAC+ group (compare F with E). Asterisks indicate sites where the cement samples were located (C-F). In situ alkaline phosphatase activity was significantly higher for cultures grown in the presence of CAC+ compared with MTA (compared H with G; G,H: transmitted light; G,H insets: epifluorescence). 


\section{DISCUSSION}

The present study showed that exposure to $\mathrm{CAC}+$ supports the progression of a higher number of cells with a more differentiated osteoblastic phenotype compared with MTA. Indeed, significantly higher values in terms of total cell number, protein content, and ALP activity were detected for $\mathrm{CAC}+$-exposed cultures. These results were supported by morphologic and histochemical findings.

One possible explanation for the changes observed between CAC+ and MTA-exposed cultures could be related to the differences in terms of calcium hydroxide release from the cement preparations, which has been determined to be lower for CAC + compared with MTA $(5,11)$. Noteworthy, during the whole culture interval, the edges of $\mathrm{CAC}+$ samples were sharper than the MTA ones, suggesting lower dissolution rate and ultimately lower calcium hydroxide release for $\mathrm{CAC}+$ cement under the culture conditions used. In addition, because of the dissociation of calcium hydroxide in the culture medium, differences in calcium and hydroxyl concentrations between groups should
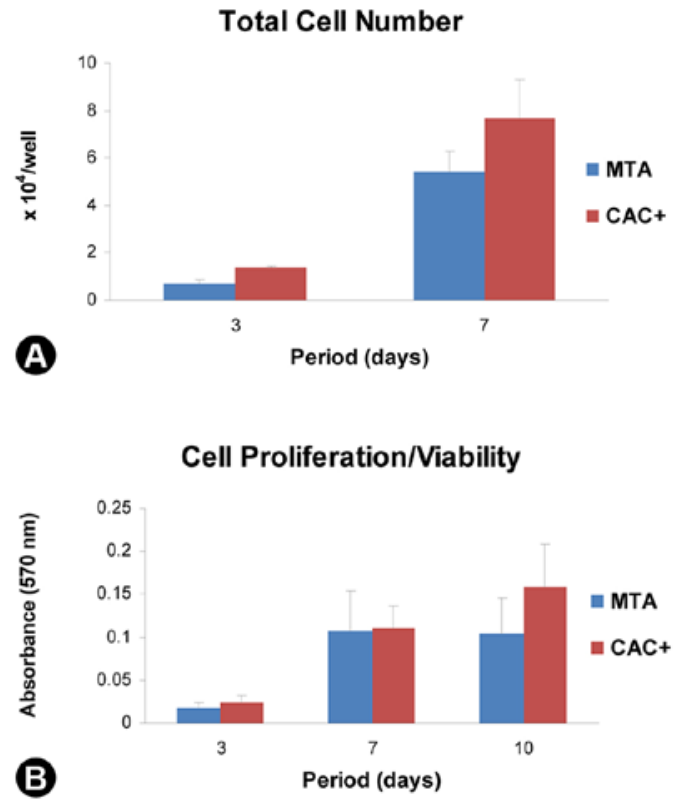

Figure 2. Total cell number of calvaria-derived osteogenic cells grown on glass coverslips in the presence of either MTA or CAC+ samples at days 3 and 7 (A). A significantly higher number of cells were detected for $\mathrm{CAC}+$ group. Cell proliferation/viability of calvaria-derived osteogenic cells grown on glass coverslips in the presence of either MTA or CAC + samples at days 3, 7 and 10 (B). Although cell proliferation/viability was affected by the culture period, no significant differences between MTA and $\mathrm{CAC}+$ were detected. Data are reported as mean $\pm \mathrm{SD}$. also take place. Whereas slightly higher extracellular calcium concentration than physiological values has been shown to stimulate osteoblast cell viability, proliferation, differentiation, and function (16), cellular calcium overload can cause cytotoxicity and trigger either apoptotic or necrotic cell death (17). Concerning the hydroxyl ion concentration, its higher levels have been directly correlated with altered extracellular matrix organization, reduced ALP activity, and bone-like nodule formation in osteogenic cell cultures (18).

In the present study, the exposure to $\mathrm{CAC}+$ samples allowed the progression of a higher cell population density with higher ALP activity compared with MTA, as judged by the biochemical measurements and Fast red staining. Although the role of ALP in bone formation is still not fully understood and subjected to controversies, such enzyme has been routinely used as an early marker of osteoblast differentiation (19). During bone matrix mineralization, ALP generates the inorganic phosphate needed for hydroxyapatite crystallization and might also hydrolyze pyrophosphate, a mineralization inhibitor, to facilitate mineral precipitation and growth (20).

The stoichiometric relation between calcia and alumina inherent to calcium aluminate cement preparations, which is the base of $\mathrm{CAC}+$ composition,
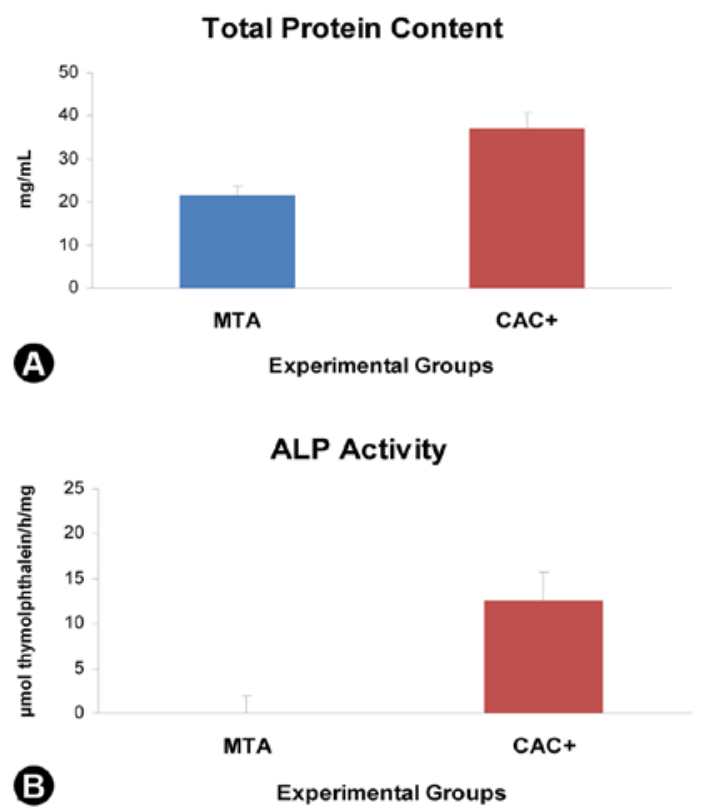

Figure 3. Total protein content (A) and ALP activity (B) of calvaria-derived osteogenic cells grown on glass coverslips in the presence of either MTA or CAC + samples at day 10 . Significantly higher values were detected for cultures grown in the presence of $\mathrm{CAC}+$. Data are reported as mean $\pm \mathrm{SD}$. 
renders tailoring of calcium hydroxide leaching as a possible production route. Based on this aspect, different calcium aluminate-based endodontic cement formulations could be designed with various levels of calcium hydroxide release adequate for different potential applications in endodontic therapies, depending on the need for either a more physiological $\mathrm{pH}$ (i.e. pulpotomy) or a more alkaline environment (i.e. alkalinity shock for dental trauma approaches).

In conclusion, the present in vitro results demonstrated that the exposure of primary osteogenic cell cultures to $\mathrm{CAC}+$ samples could be more suitable for the early differentiation of a higher osteoblastic cell population compared with the cultures exposed to MTA. Therefore, this novel calcium aluminate cement should be considered as an alternative to MTA cement preparations in root canal therapy, especially when mineralized tissue repair and/or regeneration is a desired outcome.

\section{RESUMO}

O objetivo do presente estudo foi avaliar a progressão de cultura de células osteogênicas expostas a um novo cimento de aluminato de cálcio $(\mathrm{CAC}+)$ em comparação ao agregado de trióxido mineral (MTA). As células foram obtidas por digestão enzimática de calvária de ratos recém-nascidos, plaqueadas sobre lamínulas de vidro contendo em sua área central discos de CAC+ ou MTA e crescidas em condições osteogênicas por até 10 dias. Durante a cultura primária, observou-se o arredondamento das bordas das amostras de cimento apenas para MTA. Embora ambos os cimentos tenham permitido a adesão, o espraiamento e a proliferação celulares, as culturas crescidas em contato com CAC+ exibiram valores maiores de número total de células em 3 e 7 dias, e de conteúdo de proteína total e atividade de fosfatase alcalina em 10 dias. Os resultados indicam que a exposição ao $\mathrm{CAC}+$ permite o desenvolvimento de uma proporção maior de células em estágios mais avançados da diferenciação osteoblástica, quando comparado ao MTA. Deve-se considerar em futuros estudos experimentais a utilização do CAC+ como um material alternativo ao MTA especialmente quando um dos objetivos do tratamento endodôntico é o de reparação dos tecidos mineralizados da região periapical.

\section{ACKNOWLEDGEMENTS}

This study was supported by the State of São Paulo Research Foundation (FAPESP, Brazil). Larissa Moreira Spinola de CastroRaucci is the recipient of a Doctoral scholarship from FAPESP. Lucas Novaes Teixeira was the recipient of a scholarship from the National Council of Scientific and Technological Development (CNPq, Brazil). The authors thank Roger Rodrigo Fernandes (Ribeirão Preto Dental School, University of São Paulo) for technical assistance and Embrarad for sterilization of cement samples.

\section{REFERENCES}

1. Koh ET, McDonald F, Pitt Ford TR, Torabinejad M. Cellular response to Mineral Trioxide Aggregate. J Endod 1998:24:543-547.

2. Mitchell PJ, Pitt Ford TR, Torabinejad M, McDonald F. Osteoblast biocompatibility of mineral trioxide aggregate. Biomaterials 1999:20:167-173.

3. Zhu Q, Haglund R, Safavi KE, Spangberg LS. Adhesion of human osteoblasts on root-end filling materials. J Endod 2000:26:404-406

4. Al-Rabeah E, Perinpanayagam H, MacFarland D. Human alveolar bone cells interact with ProRoot and tooth-colored MTA. J Endod 2006:32:872-875.

5. Pandolfelli VC, Oliveira IR, Rossetto HL, Jacobovitz M. A composition based on aluminate cement for application in endodontics and the obtained cement product. Patent registration INPI 0704502-6. Assignee: Fundação Universidade Federal de São Carlos, November 29, 2007 (in Portuguese).

6. Jacobovitz M, de Lima RKP. Treatment of inflammatory internal root resorption with mineral trioxide aggregate: a case report. Int Endod J 2008:41:905-912.

7 Ber BS, Hatton JF, Stewart GP. Chemical modification of ProRoot MTA to improve handling characteristics and decrease setting time. J Endod 2007:33:1231-1234.

8. Bortoluzzi EA, Broon NJ, Bramante CM, Consolaro A, Garcia RB, de Moraes IG, et al.. Mineral trioxide aggregate with or without calcium chloride in pulpotomy. J Endod 2008:34:172-175.

9. Camilleri J. Characterization and chemical activity of Portland cement and two experimental cements with potential for use in dentistry. Int Endod J 2008:41:791-799.

10. Torabinejad M, Chivian N. Clinical applications of mineral trioxide aggregate. J Endod 1999:25:197-205.

11. Oliveira IR, Pandolfelli VC, Jacobovitz M. Chemical, physical and mechanical properties of a novel calcium aluminate endodontic cement. Int Endod J 2010;43:1069-1076.

12. Jacobovitz M, Vianna ME, Pandolfelli VC, Oliveira IR, Rossetto HL, Gomes BPFA. Root canal filling with cements based on mineral aggregates: An "in vitro" analysis of bacterial microleakage. Oral Surg Oral Med Oral Pathol Oral Radiol Endod 2009:108:140-144.

13. De Oliva MA, Maximiano WM, de Castro LM, da Silva PE Jr, Fernandes RR, Ciancaglini P, et al.. Treatment with a growth factor-protein mixture inhibits formation of mineralized nodules in osteogenic cell cultures grown on titanium. J Histochem Cytochem 2009:57:265-276.

14. Mosmann T. Rapid colorimetric assay for cellular growth and survival: application to proliferation and cytotoxicity assays. J Immunol Methods 1983:65:55-63.

15. Majors AK, Boehm CA, Nitto H, Midura RJ, Muschler GF. Characterization of human bone marrow stromal cells with respect to osteoblastic differentiation. J Orthop Res 1997:15:546-57.

16. Dvorak MM, Siddiqua A, Ward DT, Carter DH, Dallas SL, Nemeth EF, et al.. Physiological changes in extracellular calcium concentration directly control osteoblast function in the absence of calciotropic hormones. Proc Natl Acad Sci USA 2004:101:5140-5145.

17. Orrenius S, Zhivotovsky B, Nicotera P. Regulation of cell death: the calcium apoptosis link. Nat Rev Mol Cell Biol 2003:4:552-565.

18. Hosoya S, Suzuki H, Yamamoto M, Kobayashi K, Abiko Y. Alkaline phosphatase and type I collagen gene expressions were reduced by hydroxyl radical-treated fibronectin substratum. Mol Genet Metab 1998:65:31-34.

19. Karsenty G. Transcriptional regulation of osteoblast differentiation during development. Front Biosci 1998:3:d834-d837.

20. Bonucci E. Main suggested calcification mechanisms: cells. In: Biological calcification: normal and pathological processes in the early stages. Berlin-Heidelberg: Springer 2007:491-506. 